\title{
Investigation of the influence of gear milling modes of cylindrical gears on the quality parameters of tooth surfaces
}

\author{
Mark Kane, Valery Sheleg, Marina Kravchuk, and Pavel Kot
}

Belarusian national technical University, Department of mechanical engineering Technology, 65 Nezavisimosti Avenue, 220013, Minsk, Belarus

\begin{abstract}
Summary. The current state of the problem of studying the influence of gear milling modes of cylindrical gears on the quality parameters of the tooth surfaces is considered. Insufficient study of this problem and inconsistency of the available results is shown. The relevance and possible areas of application of this research are shown. The research objects are described (the effect of the cutting speed $\mathrm{V}$ and feed $\mathrm{S}$ during hobbing of cylindrical gears on the roughness parameter Ra, microhardness $\mathrm{H} \mu$, residual stresses 1 and 2, $\sigma 1$ and $\sigma 2$ in the tooth surfaces), the accepted methods of planning experiments and presenting results. The results obtained are presented. It is established that the considered relationships can be modeled with sufficient accuracy by statistical methods and can be described by polynomials of the first or second degree. Shows the nature of the change $\mathrm{Ra}, \mathrm{H} \mu, \sigma 1$ and $\sigma 2$, with changes of $\mathrm{V}$ and $\mathrm{S}$. Given are calculated according to $\mathrm{Ra}, \mathrm{H} \mu, \sigma 1$ and $\sigma 2$ from $\mathrm{V}$ and $\mathrm{S}$.
\end{abstract}

\section{Status of the issue}

The influence of gear milling modes of cylindrical gears on the quality parameters of tooth surfaces has not been sufficiently studied.

Researches by A. A. Matalin, P. E. Dyachenko, P. I. Lizardsyn, E. V. Ryzhov, A. G. Suslov, V. P. Fedorov, N. A. Podosenova, G. A. Deryagin, I. A. Birger, V. A. Kravchenko, and others allowed us to establish the nature of the formation of the main characteristics of surface quality during turning, milling, grinding, and some final methods of diamondabrasive and finishing-strengthening processing. It was shown, in particular, that the feed has the greatest effect on the cutting forces and the level of deformation hardening (hardening) of the surface of the workpiece. The cutting speed determines to a large extent the temperature in the cutting zone, the duration of the impact of deforming forces on the metal. Therefore, as the cutting speed increases, de-hardening processes may occur, surface hardening of the workpiece, the occurrence of tensile residual stresses, etc. The increase in feed causes an increase in roughness, the degree and depth of the incrustation, compressive residual stresses.

General view of the dependencies of the roughness parameter $\mathrm{Rz}$ of the cut surface on the cutting speed $\mathrm{V}$ and feed $\mathrm{S}$ is shown in Fig. 1 [1].

Micro-irregularities of the processed surfaces are formed under the action of the build-up on the cutting edges of the tool and the cutting forces. The size of the build-up depends on the properties of the material being processed and the temperature in the cutting zone.
Low-carbon steels (18ХГТ, 12ХН3А, 25ХГТ*, etc. according to ГОСТ 4543-71 (Rus,)) are often used for the manufacture of cylindrical gears. These materials are plastic and prone to build-up. In Fig.1.a shows the effect of $\mathrm{V}$ on $\mathrm{Rz}$ for a material that is prone to build-up (curve 1) and for a processed material that is not prone to build-up (curve 2). In areas of low (for steel up to $10 \mathrm{~m} / \mathrm{min}$ ) and high speeds (for steel over 50 $\mathrm{m} / \mathrm{min}$ ), the build-up is reduced and the $\mathrm{Rz}$ values are reduced.

The complex nature of the dependence of the roughness on the feed can be explained by the fact that when the latter decreases, the thickness of the cut also decreases. The radius of rounding of the cutting edge is commensurate with the thickness of the cut and the chip formation process in such conditions becomes unstable, resulting in increased friction forces on the back surface and the height of the micro-surfaces. Increasing $\mathrm{S}$ increases the unevenness of the cutting forces and the vibration in the cutting zone. This leads to more frequent removal of the growth and an increase in $\mathrm{Rz}$ values.

The circumferential cutting force - the main component of the resultant metal resistance force to cutting - can be calculated using the formula

$$
\mathrm{P}_{\mathrm{z}}=\mathrm{C}_{\mathrm{p}} \mathrm{m}^{1.4} \mathrm{~S}^{0.95} \mathrm{~V}^{-0.28} \mathrm{t}^{1,4} \mathrm{k}_{10} \mathrm{k}_{\mathrm{M}} 9.8,
$$

where $\mathrm{Cp}$ is the coefficient that takes into account the influence of constant factors on the cutting force (for hobs $\mathrm{Cp}=15) ; \mathrm{k}_{10}$ - coefficient taking into account the number of hob threads (if the number of calls $\mathrm{z}_{10}=1 \mathrm{k}_{10}$ $=1) ; \mathrm{k}_{\mathrm{M}}=1 \ldots .0 .5-$ coefficient taking into account the hardness of the material of the wheels (for example, 
steel $45 \mathrm{k}_{\mathrm{M}}=1$ ); $\mathrm{m}$ is the module of the teeth of the

wheel; $\mathrm{t}$ is the slice thickness, $\mathrm{mm}$.

* Note: steel 18 ХГТ - $1.3 \mathrm{chr} 0.23$ carb 1,1 mang $0.37 \mathrm{sil}$; steel $12 \mathrm{XH} 3 \mathrm{~A}-1.2$ carb $1,5 \mathrm{chr} 3$ nick; steel $25 \mathrm{XГT}-0.24$ carb 0.23 sil 1,0 mang $1.1 \mathrm{chr}$

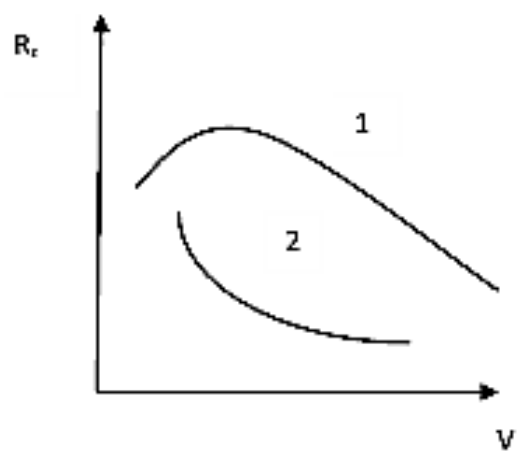

Fig.1. Typical dependencies $R z=f(V)$ and $R z=f(S)$

When gear cutting cylindrical gears, as well as when cutting in General, the change in cutting forces affects the main characteristics of the quality of the treated surface. Based on the kinematics of gear cutting with worm cutters, the values of $\mathrm{S}$ and $\mathrm{t}$ are closely related. An increase in $\mathrm{S}$ leads to an increase in $\mathrm{t}$.

Thus, with the specified parameters of the cut wheel (z. m) and the worm cutter (cutting angles, radius of rounding of the cutting edge, material), the main factors affecting the micro-dimensions of the cut teeth when the worm cutter is used are the cutting modes $\mathrm{V}$ and $\mathrm{S}$ and the hardness $\mathrm{HB}$ of the processed material. However, the study [3] of the influence of $\mathrm{V}$, $\mathrm{S}$, and $\mathrm{HB}$ on the $\mathrm{R}_{\mathrm{z}}$ value of the processed teeth during gear milling with worm cutters showed that the influence of $\mathrm{S}$ on $\mathrm{Rz}$ is small (it increases with the increase in the modulus of the processed teeth), and the influence of $\mathrm{HB}$ is practically absent. At the same time, it is noted in [2] that the feed value is limited by the requirements for roughness and undulation of the tooth surface. These contradictory results indicate the need to clarify the influence of tooth milling modes on the parameter of tooth surface roughness in modern

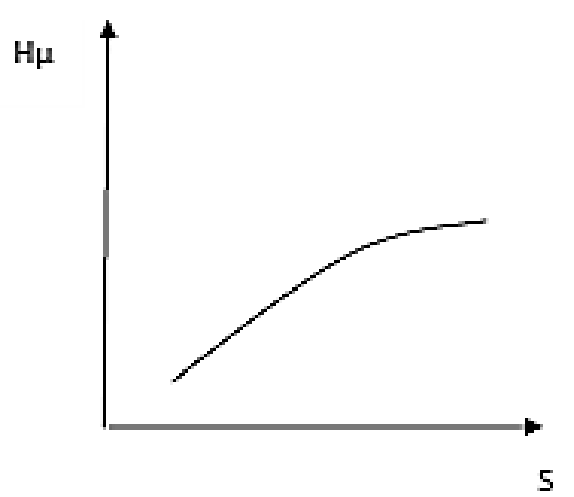

a)

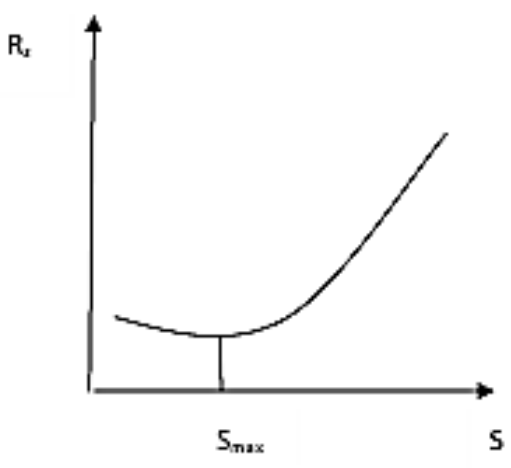

conditions of tooth processing.

When cutting metals under the influence of force and heat processes in the cutting zone, the phenomena of hardening and softening of the metal occur, the microhardness of the treated surface changes and there are residual stresses in the surface layer. When cutting, the plastic deformation causes the surface to tilt, due to which the latter is strengthened and increases microhardness of the treated surface, there are residual stresses in the surface layer and reduced plasticity.. Heating the metal during cutting leads to its softening, partial return to its original state. The final state of the surface layer is determined by the ratio of hardening and softening processes that depend on the predominance of force or heat factors in the cutting zone. A certain role in the interaction of these processes can be played by the properties of the metal, characterized, in particular, by its hardness HB. In Fig.2 shows the typical dependence of the microhardness of the surface of $\mathrm{H}_{\mu}$ on the cutting modes [ 1].

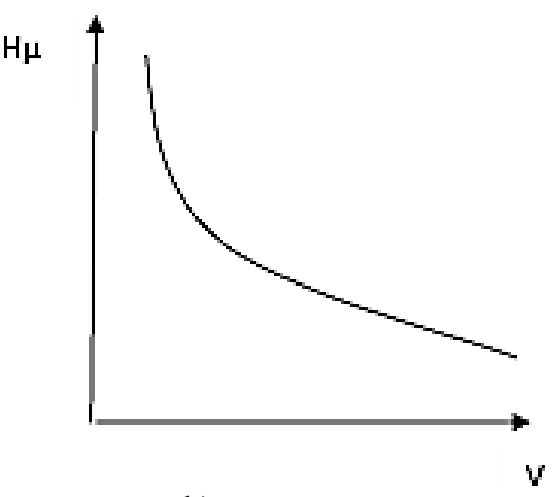

b)

Fig.2.The dependence of the microhardness of the surface H (the degree of its hardening) on the feed $\mathrm{S}$ (a) and the cutting speed V (b).

Residual stresses in the surface layer during cutting occur as a result of the interaction of statically and elastically deformed layers. As shown by our research [4], when tooth milling occurs in the surface of the teeth, tensile stresses of the first kind of the order of 
$260 \ldots 430 \mathrm{MPa}$, depending on the material of the wheels. Studies of the effect of cutting modes of cylindrical gear teeth on residual stresses in the tooth surfaces have not been performed before.

Thus, the main factors that determine the quality characteristics of the surfaces of the teeth of cylindrical gears when they are cut with worm cutters under specified processing conditions (parameters of the gear being processed and the worm cutter) are the cutting modes $\mathrm{S}$ and $\mathrm{V}$.

To design the manufacturing processes of cylindrical gears, it is necessary to know the degree of influence of cutting modes on various parameters of their quality. Our analysis of postoperative changes in the quality characteristics of the tooth surfaces when processing cylindrical gears [4] showed that there is a technological inheritance of these characteristics in the main operations of tooth processing. As a result, up to $54 \%$ of the dispersion of these characteristics is formed during gear cutting for gears that have passed after gear cutting operations of shewing, chemical and heat treatment, tooth-honing, and tooth-rolling. Knowing the relationship between the quality characteristics of the tooth surfaces and the gear milling modes opens up the possibility of controlling these characteristics, both in gear milling and in finished gears.

Thus, the analysis of the issue status allows us to draw the following conclusions:

1. The influence of cutting modes on the quality parameters of the teeth surfaces of cylindrical gears of medium modules $(\mathrm{m}=2.5-5.0 \mathrm{~mm})$ should take place. However, these relationships have not been studied enough and the findings are contradictory.

2. Knowledge of these relationships will improve the quality of the design of technological processes for manufacturing cylindrical gears, will open up opportunities for managing the quality of gears by selecting rational values of gear milling modes.

3. The problem of studying the influence of gear milling modes of cylindrical gears of medium modules in modern production conditions on the quality parameters of the tooth surfaces is relevant.

\section{Research method}

The study was carried out in the conditions of the Minsk gear plant on a gear milling machine mod.5B312 when processing gears $(\mathrm{m}=3-5 \mathrm{~mm}$, ) made of $25 \mathrm{XГT,} 40 \mathrm{X}$, 20XH3A steel, which are typical for auto-tractor transmission gears.

First we performed a study of the form of correlation dependencies of the considered parameters of the quality of gears on the modes of gear milling according to the scheme a complete factor experiment (CFE) with the addition of 5 experiments in the center of the plan.

The experiment planning matrix used is shown in table 1.

The analysis of the obtained regression lines allowed us to assume that the relationships of $\mathrm{Ra}$ with $\mathrm{V}$ and $\mathrm{S}$ can be considered linear, and $H_{\mu}, \sigma_{1}$ and $\sigma_{2}$ with $\mathrm{V}$ and $\mathrm{S}$ - nonlinear. Therefore, in the future, more in-depth studies of these relationships for linear dependence were performed according to the PFE scheme (the first 4 experiments in table. 1), and for nonlinear dependencies - according to the scheme of rotatable central composition planning (RCCP), the matrix of which is shown in table 2.

Table 1. Matrix of the experiment in the preliminary study of the relationship between the quality parameters of the gear tooth surfaces and the gear milling modes.

\begin{tabular}{|c|c|c|c|c|c|}
\hline \multirow{2}{*}{$\begin{array}{l}\text { Number } \\
\text { experience's }\end{array}$} & \multicolumn{2}{|c|}{ Factors } & \multicolumn{3}{|c|}{ The results of the parallel experiments } \\
\hline & $\mathrm{X}_{1}$ & $\mathrm{X}_{2}$ & $Y_{j 1}$ & $\mathrm{Y}_{\mathrm{j} 2}$ & $\mathrm{Y}_{\mathrm{j} 3}$ \\
\hline 1. & -1 & -1 & $\mathrm{Y}_{11}$ & $\mathrm{Y}_{12}$ & $\mathrm{Y}_{13}$ \\
\hline 2. & +1 & -1 & $\mathrm{Y}_{21}$ & $Y_{22}$ & $\mathrm{Y}_{23}$ \\
\hline 3. & -1 & +1 & $\mathrm{Y}_{31}$ & $\mathrm{Y}_{32}$ & $\mathrm{Y}_{33}$ \\
\hline 4. & +1 & +1 & $\mathrm{Y}_{41}$ & $\mathrm{Y}_{42}$ & $\mathrm{Y}_{43}$ \\
\hline 5. & 0 & -1 & $\mathrm{Y}_{51}$ & $\mathrm{Y}_{52}$ & $\mathrm{Y}_{53}$ \\
\hline 6. & -1 & 0 & $\mathrm{Y}_{61}$ & $\mathrm{Y}_{62}$ & $\mathrm{Y}_{63}$ \\
\hline 7. & +1 & 0 & $\mathrm{Y}_{71}$ & $Y_{72}$ & $Y_{73}$ \\
\hline 8. & 0 & +1 & $\mathrm{Y}_{81}$ & $Y_{82}$ & $Y_{83}$ \\
\hline 9. & 0 & 0 & $Y_{91}$ & $Y_{92}$ & $Y_{93}$ \\
\hline $\begin{array}{l}X_{1}-\text { cuttis } \\
X_{2}-\text { feed } \\
(-1)-\text { low } \\
(+1)-\text { upp } \\
(0)-\text { aver }\end{array}$ & $\begin{array}{l}\mathrm{V}, \mathrm{r} \\
\min \\
\text { of } \mathrm{X} \\
\text { of } \mathrm{X} \\
\text { of } \mathrm{Y}\end{array}$ & & & & \\
\hline
\end{tabular}


Table 2. RCKP matrix of the experiment.

\begin{tabular}{|c|c|c|c|c|c|c|c|c|c|}
\hline \multirow{2}{*}{$\begin{array}{c}\text { Experiment } \\
\text { system }\end{array}$} & \multirow{2}{*}{$\begin{array}{c}\text { Number } \\
\text { experience's }\end{array}$} & \multirow[t]{2}{*}{$\mathrm{X}_{1}$} & \multirow[t]{2}{*}{$\mathrm{X}_{2}$} & \multirow[t]{2}{*}{$\mathrm{X}_{1} \mathrm{X}_{2}$} & \multirow[t]{2}{*}{$\mathrm{X}_{1}^{2}$} & \multirow[t]{2}{*}{$\mathrm{X}_{2}{ }^{2}$} & \multicolumn{3}{|c|}{$\begin{array}{l}\text { The results of the parallel } \\
\text { experiments }\end{array}$} \\
\hline & & & & & & & $\mathrm{Y}_{\mathrm{j} 1}$ & $\mathrm{Y}_{\mathrm{j} 2}$ & $Y_{j 3}$ \\
\hline \multirow{4}{*}{$\begin{array}{c}\text { Full } \\
\text { factorial } \\
\text { experiment } \\
\left(\mathrm{N}_{1}\right)\end{array}$} & 1. & -1 & -1 & +1 & +1 & +1 & $\mathrm{Y}_{11}$ & $\mathrm{Y}_{12}$ & $\mathrm{Y}_{13}$ \\
\hline & 2. & +1 & -1 & -1 & +1 & +1 & $\mathrm{Y}_{21}$ & $\mathrm{Y}_{22}$ & $\mathrm{Y}_{23}$ \\
\hline & 3. & -1 & +1 & -1 & +1 & +1 & $\mathrm{Y}_{31}$ & $\mathrm{Y}_{32}$ & $\mathrm{Y}_{33}$ \\
\hline & 4. & +1 & +1 & +1 & +1 & +1 & $\mathrm{Y}_{41}$ & $\mathrm{Y}_{42}$ & $\mathrm{Y}_{43}$ \\
\hline \multirow{4}{*}{$\begin{array}{c}\text { Experiments in } \\
\text { «star } \\
\text { points» } \\
\left(\mathrm{N}_{2}\right) \\
\end{array}$} & 5. & +1.41 & 0 & 0 & 2.0 & 0 & $\mathrm{Y}_{51}$ & $\mathrm{Y}_{52}$ & $\mathrm{Y}_{53}$ \\
\hline & 6. & -1.41 & 0 & 0 & 2.0 & 0 & $\mathrm{Y}_{61}$ & $\mathrm{Y}_{62}$ & $Y_{63}$ \\
\hline & 7. & 0 & +1.41 & 0 & 0 & 2.0 & $\mathrm{Y}_{71}$ & $\mathrm{Y}_{72}$ & $\mathrm{Y}_{73}$ \\
\hline & 8. & 0 & -1.41 & 0 & 0 & 2.0 & $\mathrm{Y}_{81}$ & $\mathrm{Y}_{82}$ & $\mathrm{Y}_{83}$ \\
\hline \multirow{5}{*}{$\begin{array}{c}\text { Experiences } \\
\text { in the centre } \\
\text { plan's } \\
\left(\mathrm{N}_{0}\right)\end{array}$} & 9. & 0 & 0 & 0 & 0 & 0 & $\mathrm{Y}_{91}$ & $\mathrm{Y}_{92}$ & $\mathrm{Y}_{93}$ \\
\hline & 10. & 0 & 0 & 0 & 0 & 0 & $Y_{101}$ & $Y_{102}$ & $\mathrm{Y}_{103}$ \\
\hline & 11. & 0 & 0 & 0 & 0 & 0 & $Y_{111}$ & $Y_{112}$ & $\mathrm{Y}_{113}$ \\
\hline & 12. & 0 & 0 & 0 & 0 & 0 & $Y_{121}$ & $Y_{122}$ & $\mathrm{Y}_{123}$ \\
\hline & 13. & 0 & 0 & 0 & 0 & 0 & $Y_{131}$ & $Y_{132}$ & $\mathrm{Y}_{133}$ \\
\hline
\end{tabular}

Measurements according to the CFE and RCCP scheme were performed when processing gears on the same machine with one worm mill at its constant setting. Each experiment was repeated 3 times. To measure the quality parameters of the tooth surface after gear milling, 4 teeth were cut out of the processed gear, evenly spaced around the wheel circumference. Out of 4 measurement results for each tooth, the maximum value was used in the calculations. Ra measurements were made using a Profiler-Profiler in 3 zones of tooth height (at the apex, in the zone of the pitch circle and at the tooth cavity). The average of the three values obtained was taken as the $\mathrm{Ra}$ value for this tooth. $\mathrm{H}_{\mu}$ measurements were made at 3 points along the width of the tooth in the zone of the pitch circle. The average value of 3 measurements was taken into account for each tooth. Measurements $\sigma_{1}$ and $\sigma_{2}$ were performed by $\mathrm{x}$-ray method.

The choice of intervals for changing the modes of gear cutting of cylindrical gears was made by us taking into account the recommendations of the technical literature [2-5], production experience and capabilities of gear cutting equipment. The accepted intervals for changing the tooth milling modes in the performed studies are shown in table 3 .

Table 3. Main characteristics of experiment plans.

\begin{tabular}{|l|c|c|}
\hline $\begin{array}{c}\text { Characteristics of the } \\
\text { experiment plan }\end{array}$ & $\begin{array}{c}\mathrm{X}_{1}(\mathrm{~V}, \\
\mathrm{m} / \mathrm{min})\end{array}$ & $\begin{array}{c}\mathrm{X}_{2}(\mathrm{~S}, \\
\mathrm{mm} / \mathrm{min})\end{array}$ \\
\hline Basic level & 32.8 & 6.25 \\
\hline The range of variation in & 7.6 & 3.75 \\
\hline Upper level & 40.4 & 10.0 \\
\hline Lower level & 25.2 & 2.5 \\
\hline
\end{tabular}

When studying the linear dependence $R a=f(V, S)$, its approximation was performed using a polynomial of the first degree of the form

$$
\mathrm{Ra}=\mathrm{b}_{0}+\mathrm{b}_{1} \mathrm{~V}+\mathrm{b}_{2} \mathrm{~S}
$$

In the study of nonlinear dependencies $\mathrm{H}_{\mu}=\mathrm{f}(\mathrm{V}, \mathrm{S})$, $\sigma_{1}=\mathrm{f}(\mathrm{V}, \mathrm{S}), \quad \sigma_{2}=\mathrm{f}(\mathrm{V} . \mathrm{S}) \quad$ their approximation was performed using a second-degree polynomial of the form

$$
\mathrm{y}=\mathrm{b}_{0}+\mathrm{b}_{1} \mathrm{~V}+\mathrm{b}_{2} \mathrm{~S}+\mathrm{b}_{12} \mathrm{VS}+\mathrm{b}_{11} \mathrm{~V}^{2}+\mathrm{b}_{22} \mathrm{~S}^{2}
$$

The analysis of the experimental data obtained, in addition to calculating the coefficients of equations (1) and (2), also included an assessment of the adequacy of the obtained dependencies, the significance of the coefficients of these equations, and the degree of influence of a particular cutting mode parameter on the considered parameters of the gear tooth surface quality. The last estimation was performed using the influence coefficients calculated according to the table. 3 and the values of the coefficients of equations (1) and (2)

$$
\begin{aligned}
& \mathrm{A}_{\mathrm{V}}=\frac{2\left|\mathrm{~b}_{1}\right|}{\Delta \mathrm{V}} \\
& \mathrm{A}_{\mathrm{S}}=\frac{2\left|\mathrm{~b}_{2}\right|}{\Delta \mathrm{S}}
\end{aligned}
$$

where $b_{1}, b_{2}$ - the coefficients of equations (1) and (2); $\Delta \mathrm{V}, \Delta \mathrm{S}$ - the steps of variation $\mathrm{V}$ and $\mathrm{S}$ according to table. 3 .

The higher the value of the coefficient of influence, the more the corresponding parameter of cutting modes affects this characteristic of the quality of the tooth surfaces.

\section{Research results}

Figures 3-6 show the empirical relationships we obtained Ra, $H \mu, \sigma_{1}$ и $\sigma_{2}$ from the cutting speed $\mathrm{V}$ and feed $\mathrm{S}$, and in table. 4 - results of calculations of coefficients of regression equations describing the considered relationships, influence coefficients, and model adequacy indicators for $\mathrm{y}_{2}$ (Fischer's criterion $\mathrm{F}$ 
and the average relative error of the coupling equation $\left.\varepsilon_{\text {av }}\right)$.
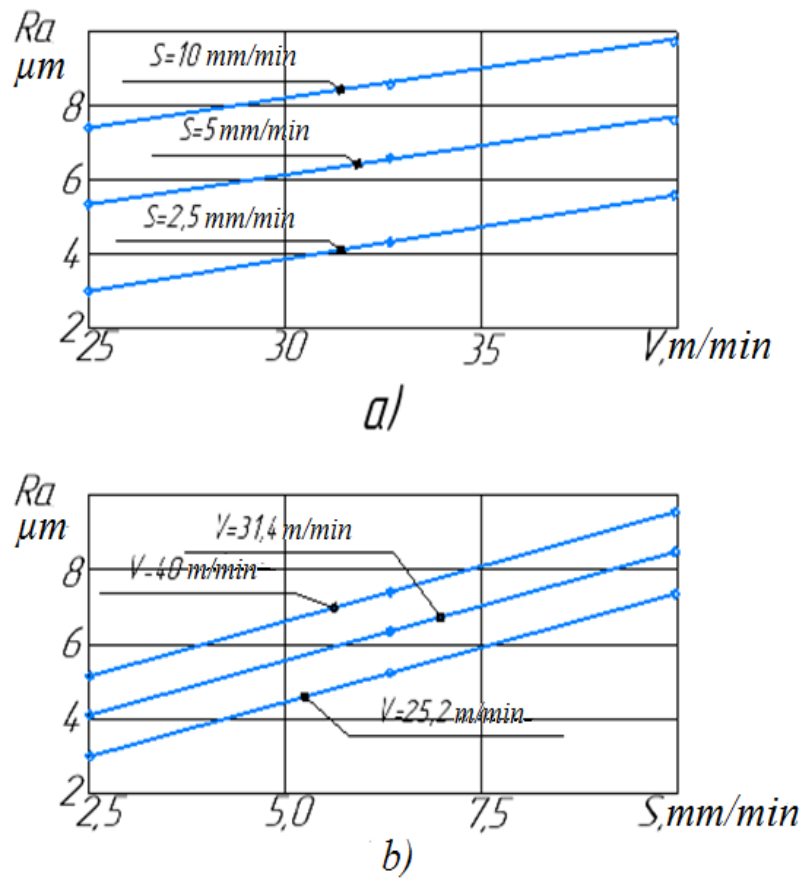

Fig.3. Empirical dependence $\mathrm{R}_{\mathrm{a}}=\mathrm{f}(\mathrm{V})$ (a) and $\mathrm{R}_{\mathrm{a}}=\mathrm{f}(\mathrm{S})$ (б) (25hgt steel).
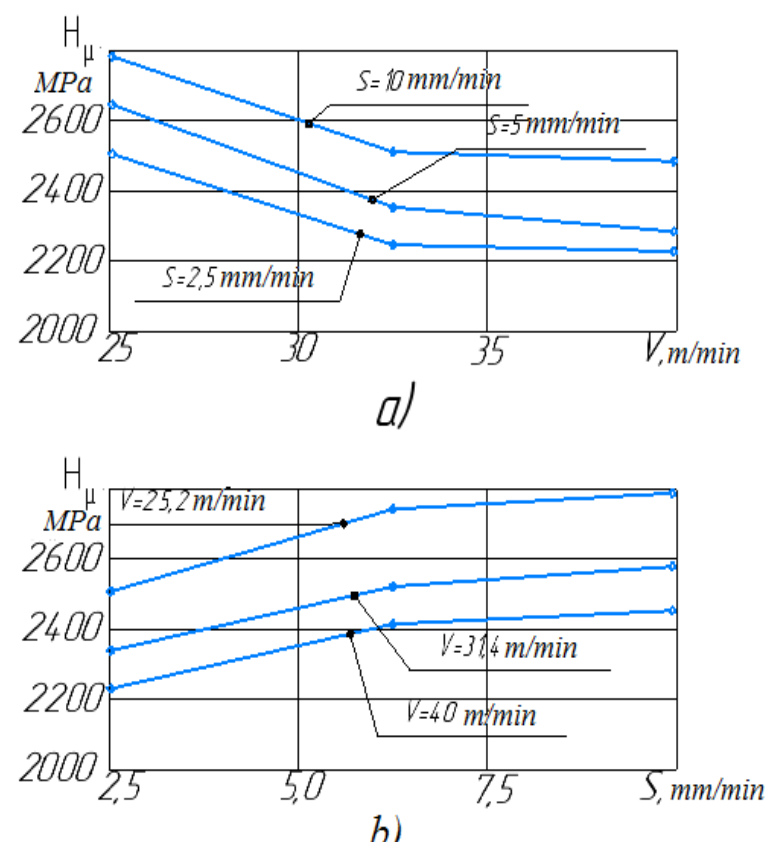

Fig.4. Empirical dependence, $H \mu=f(V)$ (a) and $H \mu=$ $\mathrm{f}(\mathrm{S})$ (б) (40X steel).

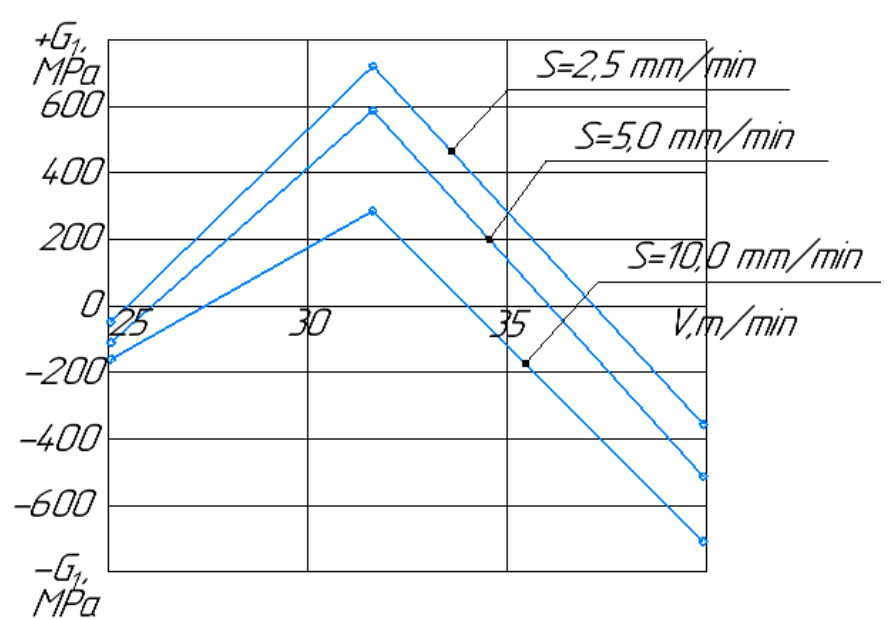

a)

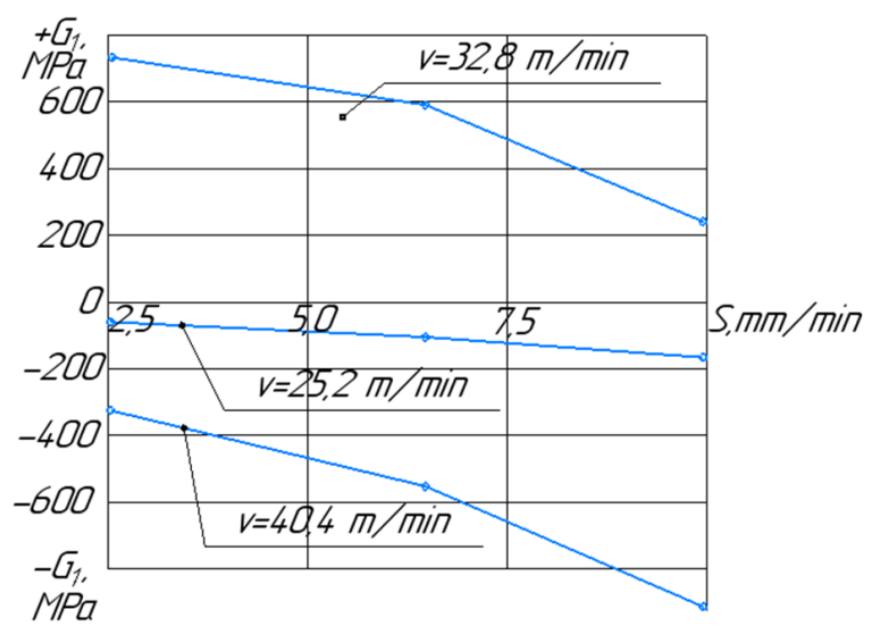

b)

Fig.5. Empirical dependence $\sigma_{1}=\mathrm{f}(\mathrm{V})$ (a) and $\sigma \mathrm{l}=\mathrm{f}(\mathrm{S})$ (б) (40x steel). 

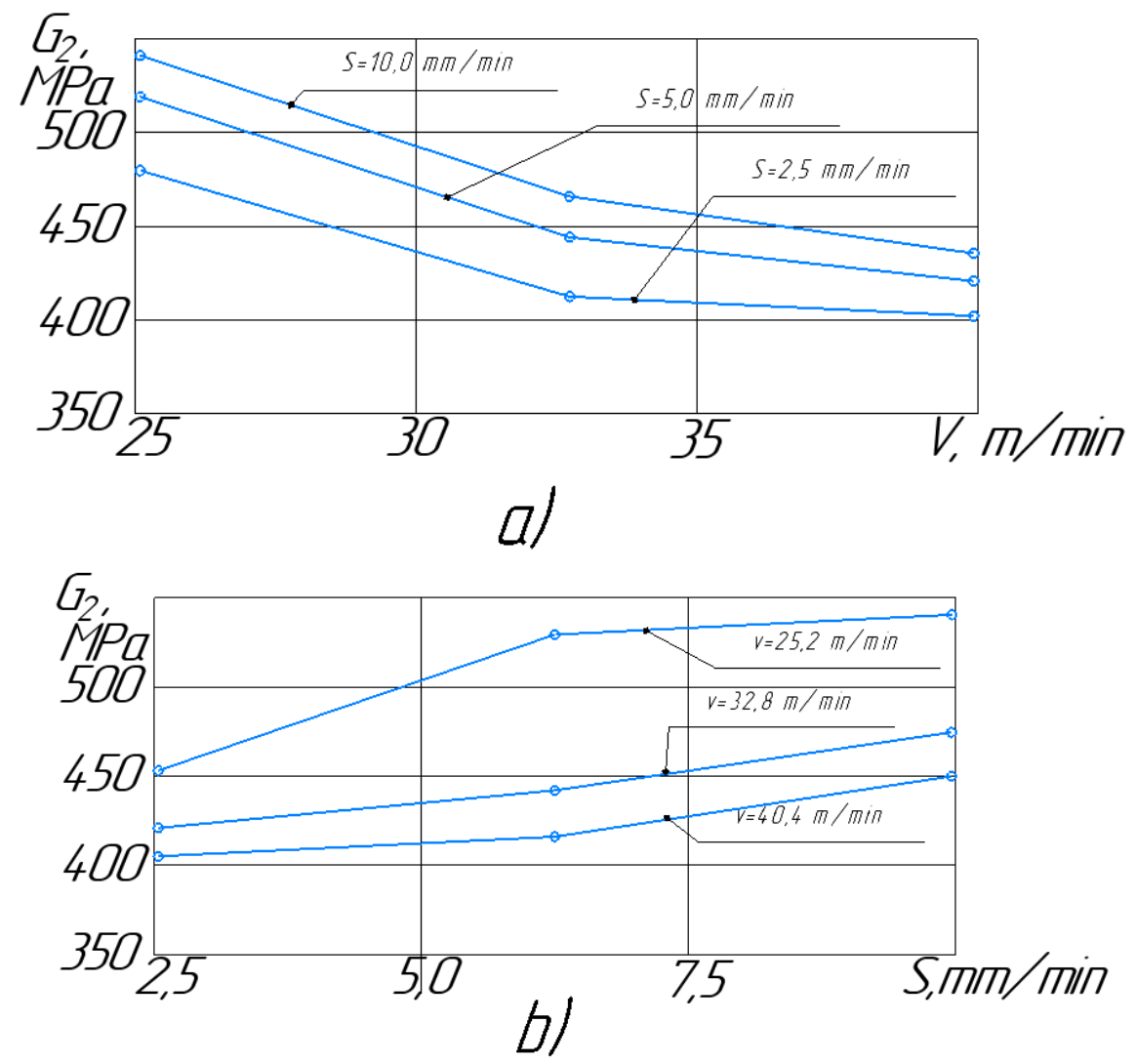

Fig. 6. Empirical dependence $\sigma_{2}=f(V)(a)$ and $\sigma_{2}=f(S)$ (б) (40x steel).

In table $4 \mathrm{y}_{1}$ - quality parameter values for equations in coded variable values $\mathrm{X}_{1}$ и $\mathrm{X}_{2}, y_{2}$ - quality parameter values for

\section{Conclusions}

1. Between the surface quality parameters of cylindrical gear teeth (roughness parameter $\mathrm{Ra}$, microns, microhardness $\mathrm{H}_{\mu}, \mathrm{MPa}$, residual stresses of the first and second kinds $\sigma_{1}$ and $\sigma_{2}, \mathrm{MPa}$ ) there are stable relationships between the modes of gear milling with worm cutters (cutting speed $\mathrm{V}, \mathrm{m} / \mathrm{min}$ and feed $\mathrm{S}$, $\mathrm{mm} / \mathrm{min}$ ), which can be described by polynomial models using experimental planning methods.

2. The calculations confirmed the reliability of the coefficients of the regression equations found using these methods, and the adequacy of these equations (for the obtained equations, the conditions are met $\mathrm{F}<\mathrm{F}_{\mathrm{cr}}$, $\left(\mathrm{F}_{\mathrm{cr}}=\mathrm{F}_{\mathrm{f} 1, \mathrm{f} 2, \mathrm{a}}=\mathrm{F}_{1.4,0,05}=7.71\right)$ и $\varepsilon_{\mathrm{av}}<30 \%$.

3. Dependence $R a=f(V, S)$ in the best degree can be described by a polynomial of the first degree, the dependence $H_{\mu}=f(V, S), \sigma_{1}=f(V, S), \sigma_{2}=f(V, S)-a$ polynomial of the second degree. Although to describe the dependency $H_{\mu}=f(V, S)$ with sufficient accuracy equations in natural units of variables $\mathrm{V}$ and $\mathrm{S}$. Values of $\mathrm{F}$ and $\varepsilon_{\mathrm{av}}$ determined by known dependencies [6].

$\left(\varepsilon_{\mathrm{av}}=8.7-26.5 \%\right)$ a polynomial of the first degree can also be used.

4. The growth of $\mathrm{V}$ causes an increase in $\mathrm{Ra}$ and decrease $\mathrm{H}_{\mu}, \sigma_{2}$. When increasing $\mathrm{V}$ to about $32 \mathrm{~m} /$ $\mathrm{min}$, there is an increase in $\sigma_{1}$, if you increase $\mathrm{V}$ further, it decreases $\sigma_{1}$. Moreover, at $37 \mathrm{~m} / \min <\mathrm{V}<26 \mathrm{~m} / \mathrm{min}$, compressive residual stresses occur in the tooth surface, which increases the life of the gears. In the range $\mathrm{V}=26-$ $37 \mathrm{~m} / \mathrm{min}$, tensile residual stresses are created in the tooth surface during gear milling with a worm cutter. Thus, the range of $37 \mathrm{~m} / \min <\mathrm{V}<26 \mathrm{~m} / \min$ can be recommended for gear milling of cylindrical gears of medium modules $(\mathrm{m}=3 \cdot 0-6.5 \mathrm{~mm})$. 
Table 4. Experimental relationships between gear milling modes $\mathrm{V}$ and $\mathrm{S}$ and the main characteristics of the tooth surface quality $\left(\mathrm{R}_{\mathrm{a}}, \mathrm{H}_{\mu}, \sigma_{1}, \sigma_{2}\right)$.

\begin{tabular}{|c|c|c|c|c|}
\hline $\begin{array}{l}\text { Quality } \\
\text { characteristics } \\
\text { surfaces teeth }\end{array}$ & $\begin{array}{l}\text { Gear } \\
\text { steel } \\
\text { grade }\end{array}$ & $\begin{array}{l}\text { Type of dependence of the tooth surface quality parameter on the } \\
\text { tooth milling modes }\end{array}$ & $\begin{array}{l}\text { Fisher } \\
\text { Criterion } \\
\quad \text { F }\end{array}$ & $\begin{array}{c}\text { Average } \\
\text { relative } \\
\text { error of the } \\
\text { coupling } \\
\text { equation } \\
\varepsilon_{\mathrm{av}}\end{array}$ \\
\hline \multirow[t]{3}{*}{$\begin{array}{l}\text { Roughness } \\
\text { parameter } \mathrm{R}_{\mathrm{a}} \\
\text { microns }\end{array}$} & $40 X$ & $\begin{array}{l}y_{1}=3.8+0.92 X_{1}+2.2 X_{2} \\
y_{2}=1.1+0.06 V+0.29 S \\
A_{V}=0.016 \quad A_{S}=0.155\end{array}$ & 1.7 & 5.2 \\
\hline & $25 \mathrm{X} \Gamma \mathrm{T}$ & $\begin{array}{l}y_{1}=6.3+0.93 X_{1}+2.12 X_{2} \\
y_{2}=2.55+0.065 V+0.27 S \\
A_{V}=0.017 \quad A_{S}=0.144\end{array}$ & 2.2 & 14.7 \\
\hline & 20XH3A & $\begin{array}{l}y_{1}=3.8+1.7 X_{1}+0.92 X_{2} \\
y_{2}=0.9+0.045 V+0.32 S \\
A_{V}=0.012 \quad A_{S}=0.171\end{array}$ & 3.5 & 26.5 \\
\hline \multirow[t]{3}{*}{$\begin{array}{l}\text { Microhardness } \\
\mathrm{H}_{\mu}, \mathrm{MPa}\end{array}$} & $40 X$ & $\begin{array}{l}\mathrm{y}_{1}=2021-73.6 \mathrm{X}_{1}+82.4 \mathrm{X}_{2}-23.7 \mathrm{X}_{1} \mathrm{X}_{2}+186 \mathrm{X}_{1}^{2}+280 \mathrm{X}_{2}^{1} \\
y_{2}=3208-40 \mathrm{~V}+50 S-0.2 \mathrm{VS}+0.9 \mathrm{~V}^{2}-5.0 S^{2} \\
A_{V}=10.5 \quad A_{S}=26.7\end{array}$ & 2.4 & 4.7 \\
\hline & $25 \mathrm{X} \Gamma \mathrm{T}$ & $\begin{array}{l}\mathrm{y}_{1}=2217.2-32.8 \mathrm{X}_{1}+97 \mathrm{X}_{2}+9.8 \mathrm{X}_{1} \mathrm{X}_{2}+4.7 \mathrm{X}_{1}^{2}-64.5 \mathrm{X}_{2}^{1} \\
y_{2}=2085-12 V+26 S+0.13 V S+0.03 V^{2}+1.2 S^{2} \\
A_{V}=3.2 \quad A_{S}=13.9\end{array}$ & 2.6 & 5.7 \\
\hline & 20XH3A & $\begin{array}{c}\mathrm{y}_{1}=2007-32 \mathrm{X}_{1}+95 \mathrm{X}_{2}+12 \mathrm{X}_{1} \mathrm{X}_{2}+5.3 \mathrm{X}_{1}^{2}-79 \mathrm{X}_{2}^{2} \\
y_{2}=1995-10 V+25 S+0.11 V S+0.02 V^{2}+1.35 S^{2} \\
A_{V}=2.6 \quad A_{S}=13.3\end{array}$ & 3.2 & 10.7 \\
\hline \multirow[t]{3}{*}{$\begin{array}{c}\text { Residual } \\
\text { stresses of the } \\
\text { first kind } \sigma_{1} \text {, } \\
\mathrm{MPa}\end{array}$} & $40 X$ & $\begin{array}{l}\mathrm{y}_{1}=442-145.1 \mathrm{X}_{1}+122.5 \mathrm{X}_{2}+122.1 \mathrm{X}_{1} \mathrm{X}_{2}-273.7 \mathrm{X}_{1}^{2}-400 \mathrm{X}_{2}^{2} \\
y_{2}=-726+67.4 \mathrm{~V}+63.9 \mathrm{~S}+1.11 \mathrm{VS}-1.3 V^{2}-68.5 S^{2} \\
A_{V}=17,7 \quad A_{S}=34,1\end{array}$ & 1.8 & 6.7 \\
\hline & $25 X Г Т$ & $\begin{array}{l}\mathrm{y}_{1}=582-184.5 \mathrm{X}_{1}+160 \mathrm{X}_{2}+126 \mathrm{X}_{1} \mathrm{X}_{2}-286 \mathrm{X}_{1}^{2}-484 \mathrm{X}_{2}^{2} \\
y_{2}=-956+83.5 \mathrm{~V}+79.7 \mathrm{~S}+1.15 \mathrm{VS}-1.4 V^{2}-82.8 S^{2} \\
A_{V}=22.0 \quad A_{S}=42.5\end{array}$ & 3.7 & 11.6 \\
\hline & $20 \mathrm{XH} 3 \mathrm{~A}$ & $\begin{array}{l}\mathrm{y}_{1}=565-196.6 \mathrm{X}_{1}+155 \mathrm{X}_{2}+132 \mathrm{X}_{1} \mathrm{X}_{2}-275 \mathrm{X}_{1}^{2}-490 \mathrm{X}_{2}^{2} \\
y_{2}=-928+84.9 \mathrm{~V}+80.9 \mathrm{~S}+1.2 \mathrm{VS}-1.35 V^{2}-83.8 S^{2} \\
A_{V}=22.3 \quad A_{S}=43.1\end{array}$ & 2.6 & 8.6 \\
\hline \multirow{3}{*}{$\begin{array}{l}\text { Residual } \\
\text { stresses of the } \\
\text { second kind } \sigma_{2} \\
\quad \mathrm{MPa}\end{array}$} & $40 X$ & $\begin{array}{l}\mathrm{y}_{1}=429.2-18 \mathrm{X}_{1}+17.9 \mathrm{X}_{2}-5.0 \mathrm{X}_{1} \mathrm{X}_{2}+27.7 \mathrm{X}_{1}^{2}+16.6 \mathrm{X}_{2}^{2} \\
y_{2}=590.4-9.5 \mathrm{~V}-0.2 \mathrm{~S}-0.05 \mathrm{VS}+0.14 V^{2}+0.28 S^{2} \\
A_{V}=2.5 \quad A_{S}=0.1\end{array}$ & 2.3 & 7.3 \\
\hline & 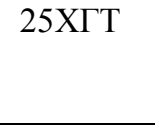 & $\begin{array}{l}\mathrm{y}_{1}=156.4-17.8 \mathrm{X}_{1}+17.7 \mathrm{X}_{2}-5.2 \mathrm{X}_{1} \mathrm{X}_{2}+54.4 \mathrm{X}_{1}^{2}+41.8 \mathrm{X}_{2}^{2} \\
y_{2}=502.4-17.7 \mathrm{~V}-4.9 \mathrm{~S}-0.07 \mathrm{VS}+0.03 V^{2}+0.7 S^{2} \\
A_{V}=4.7 \quad A_{S}=2.6\end{array}$ & 3.4 & 9.5 \\
\hline & $20 \mathrm{XH} 3 \mathrm{~A}$ & $\begin{array}{l}\mathrm{y}_{1}=263.4-21.4 \mathrm{X}_{1}+16.8 \mathrm{X}_{2}+20.5 \mathrm{X}_{1} \mathrm{X}_{2}+6.7 \mathrm{X}_{1}^{2}-4.8 \mathrm{X}_{2}^{2} \\
y_{2}=550-18 \mathrm{~V}-5.0 \mathrm{~S}-0.1 \mathrm{VS}+0.3 V^{2}-0.8 S^{2} \\
A_{V}=4.7 \quad A_{S}=2.7\end{array}$ & 4.3 & 12.8 \\
\hline
\end{tabular}


5. An increase in $\mathrm{S}$ causes an increase in $\mathrm{Ra}, \mathrm{H}_{\mu}, \sigma_{2}$, but it leads to a decrease in values $\sigma_{1}$.

6. The $\mathrm{S}$ feed has a 2.5-14 times greater effect on $\mathrm{Ra}, \mathrm{H}_{\mu}, \sigma_{1}$, than the cutting speed $\mathrm{V}$, but about 1.8 times less influence than the influence of $\mathrm{V}$ on $\sigma_{2}$. This indicates that parameter management is much more efficient $R_{a}, H_{\mu}, \sigma_{1}$ in gear milling by changing $S$ than changing $\mathrm{V}$.

7. The proposed research methods and the found dependencies can be used to select the modes of gear milling of cylindrical gears with worm cutters that provide the required values of the quality characteristics of the tooth surfaces Ra, $H_{\mu}, \sigma_{1}, \sigma_{2}$, as well as in the design of technological processes for manufacturing cylindrical gears.

\section{References}

1. Jachericyn, P. I. Cutting theory./P. I. Jachericyn, M. L. Eremenko, K. E. Feldstein.-Minsk.. New knowledge. 2006-312p.

2. The gear production: A handbook/ S. N. Kalashnikov, A. S. Kalashnikov, G. I. Kogan [and others] ; Under the General editorship of B. A. Taiz.- 2nd ed. - Moscow: Mashinostroenie,1990. $464 \mathrm{p}$.
3. Medveditskov, S. N. High-performance gear cutting with cutters. / S. N. Medveditskov. - Moscow: Mashinostroenie, 1981. - 104 p..

4. Kane M. M., Medvedev A. I. Changing the parameters of the surface quality of the teeth of cylindrical gears in various operations of their manufacture / / Vestnik mashinostroeniya, 1997, no. 7, p. 3-7.

5. Finger M. L. Cylindrical gears. Theory and practice of manufacturing / M. L. Finger. - Moscow: Scientific book, 2005. -368 p.

6.. Kane M. M. Fundamentals of research, invention and innovation in mechanical engineering: textbook.- Minsk: Higher school, 2018.-366p. 